\title{
AKT Inhibitor
}

National Cancer Institute

\section{Source}

National Cancer Institute. AKT Inhibitor. NCI Thesaurus. Code C155764.

Any agent that inhibits protein kinase B (AKT). 